\title{
Demand of the Population on Heat and Electricity Markets of the Russian Far East: limitations and consequences
}

\author{
Svetlana Naiden $^{1, *}$, and Olga Dyomina ${ }^{1}$ \\ ${ }^{1}$ Economic Research Institute of Far Eastern Branch of the Russian Academy of Sciences, Khabarovsk, Russia
}

\begin{abstract}
The paper examines the specifics of organization of the electricity and heat energy markets depending on the population behavior in the Far East. The region maintains a regular monopoly, where vertically integrated companies provide services while keeping surplus supply; consumer has no ability to influence the demand in the conditions of imposed prices. The paper estimated the price elasticity of demand on electricity for the population of Khabarovsk Krai, which confirmed the low degree of dependency of consumption from either income or the scale of the tariff. Furthermore, the paper estimated the potential growth of population expenses on electricity in two scenarios: 1) keeping energy tariffs on inflation level and 2) keeping current average annual growth rates of tariffs. There is a differentiation of availability of services depending on the level of income. There is also a need for social support of population from budgets depending on the growth rates of tariffs on electricity and heat energy.
\end{abstract}

\section{Introduction}

The theoretical assumptions on effective functioning of the markets show that consumers receive price signals from manufacturers and suppliers, compare them with their own budget capacities, and make decisions over volume of demand on goods or services. However, there are such markets where consumers have no way of controlling their demand. For example, markets of electricity or heat energy, which satisfy basic needs, which affects the market mechanism of producing and supplying these services $[1 ; 2]$. The industry specifics of such markets are reflected in the lack of price elasticity of demand on energy for some consumers, for whom the economic incentive for decreasing energy consumption is weak. A good example are the isolated energy systems with surplus capacities, where decreasing consumption leads to increasing fixed costs, which leads to increase in tariffs and consumer's expenses on energy. This paper analyses such specifics of heat energy and electricity markets in the Russian Far East.

\section{Specifics of organization of electricity and heat energy markets: consumers' behavior in the Far East}

The classic economic theory states that effectively functioning competitive markets allow consumers to change their demand on goods and services depending on the changing prices. For electricity and heat energy markets this is not always true $[3 ; 4]$. The reasons are in creation of demand and supply of energy, mainly [5-8]:
- production and consumption of electrical and heat energy happens simultaneously;

- production of electricity and heat energy is highly concentrated, their distribution is highly centralized;

- the area of electricity consumption is limited by the boundaries of effective distribution of transmission network (up to several thousand kilometers);

- heat energy markets are localized, located in settlements and separate districts of large cities (maximal radius of distribution up to 50 kilometers);

- energy demand is seasonal, which requires maintaining surplus capacities for production.

These specifics presume the existence of increasing economy of scale, require significant investments into developing the infrastructure, including early contributions into creation and development of energy systems and systems of centralized heat supply. As such, for a long time heat and electricity markets remain regulated monopolies, where vertically integrated companies provide heat and energy supply services. In these conditions the balance between demand, supply, and prices on energy is set according to the producers' wishes and the ability of regulating bodies to keep them in check. The consumers are merely the recipients of these services and have no adequate tools of influencing the quality and the price of these services. This primarily concerns population and public organizations (education, healthcare), which objectively require state patronage.

Electricity and heat supply services are essential services that satisfy basic needs, which means everyone needs to have access to them regardless of location and income according to the concept of public utility [9-10]. As such, the producer is limited in the ability to cut off

* Corresponding author: naidensvetlana@mail.ru 
consumers and suppliers of public (socially significant) sphere from these services, even if they are unable to pay. The consumer, faced with high prices on energy and limited budget, usually does not reduce consumption but instead stops paying, which creates financial debt to the producer of electricity or heat energy. This is explained by a simple fact that the consumer cannot stop using these services without reducing their quality of life. There are either no alternative ways of receiving these services at all, or they require complicated and expensive technological changes (for example, switching from centralized heat energy systems to individual heat units).

The climate conditions of the Far East make this situation more dire. Electricity and heat energy are not just essential, they are vital for survival in the harsh climate. The specifics of their production in the region is tied to significant costs. Tariffs on heat due to climatic and technological conditions of the region are traditionally the highest, 1.6 times the country average for industrial consumers, and 1.2 times the country average for general populace $[1 ; 11]$. Regional tariffs on electricity are also one of the highest in the country, despite intra-territorial cross subsidies, introduced in 2017.

Unlike the general Russian electricity market, which is competitive, where consumers sometimes can change the supply volume depending on electricity prices (pricedependent consumption was introduced in 2017), the Far East remains a regulated monopoly, where vertically integrated companies provide services and consumers are basically hostages of imposed prices. If energy saving policy were to be introduced, considering surplus energy system capacities, lack of new high-volume consumers - the decreasing demand in the region would cause increasing fixed costs and, most likely, increasing price for consumers in the Far East.

This means that consumers' behavior on the markets of electricity and heat is defined primarily by the specifics of market organization and energy qualities. In these conditions, price elasticity of demand on energy is unlikely to exist. The general empirical research that estimated coefficients of price elasticity of demand on fuel and energy showed that their values differ strongly depending on the country, industry, time period, and calculation method $[10 ; 12-17]$. Since the volume of heat consumption in most houses in the country is calculated with standards depending on the living area and its qualities, the analysis of price elasticity of demand is not expedient, unlike electricity, the consumption of which is estimated by meters.

\section{Estimation of price elasticity of demand: Khabarovsk Krai}

To analyze price elasticity of demand on electricity Khabarovsk Krai was chosen as a region most representative of the Far East. It has not only the typical spatial diversity of energy markets, but also a policy of regional patronage of essential goods and services, including investments into modernization of infrastructure of energy supply and a guarantee of social support of the population.

Looking at welfare the population of Khabarovsk Krai also represents a typical Far Easterner. There are 31.7 million square meters of housing $(16.5 \%$ of total in the Far East), where 1315 thousand people reside (16\% of total). By average nominal per capita income the population of Khabarovsk Krai is the first among the most economically developed in the south of the Far East, while having lower inequality level in income distribution (Gini coefficient of 0.388 ) - below average in Russia (0.401). The same can be said for the deciledispersion ratio (income of $10 \%$ of the wealthiest to income of $10 \%$ of the poorest) of 13 against 15.5 average in the country.

The weighted share of poor population in Khabarovsk Krai is $12.2 \%$ of the total population in the region, which is comparable to the country average value. Despite growth of nominal income per capita in 2013-2019 (141.5\%), its real volume has decreased and is even lower than it was in 2013 (only 95\%). This is made worse by poverty reproduction in, for example, northern parts of Khabarovsk Krai, which have high tariffs on electricity and heat energy and there are few opportunities presented on local job markets unlike southern parts of the region (the range of variation in income between districts inside the region is 3.5 times on average). It is impossible to provide essential goods and services, including energy supply, without state support in such conditions.

To examine the dependence between electricity consumption per capita and the housing security (living area per person), the level of average income per capita, and electricity tariffs for urban population, several functions of demand on electricity were built for two income groups: with maximal and minimal income.

Currently the whole population of Khabarovsk Krai pays for electricity according to a unified tariff regardless of the supplier and energy consumption. The analysis was carried out using the data from 2000-2017. In general, the income (price) elasticity of demand is calculated as the ratio of the percentage change of demand to the percentage change of income (price). Calculating the coefficient of price elasticity of demand for electricity is calculated as the ratio of differential logarithm of demand to differential logarithm of price. The final model estimated the demand depending on income level and tariff. The calculations allowed to formulate the following conclusions [18]:

1) There is a direct relation between demand and income level, and it differs slightly between income groups. If income grows by $1 \%$ then electricity demand increases by $0.25 \%$ for low-income population and by $0.23 \%$ for high-income population. Electricity demand does not exhibit income elasticity. This is explained by the stable living conditions and quality of life, including accessibility of household appliances (and their characteristics, intensity of usage), which have extended usage time and are renewed seldomly. Which is why the volume of electricity consumption changes only so slightly despite the growing income. 
2) The qualitative analysis has shown that population demand on electricity also does not exhibit price elasticity [3]. This is confirmed by empirical calculations done by other specialists [13]. This is explained by the fact that a certain degree of freedom in choosing an energy supplier creates only an illusion of competition, since it requires significant changes to a lifestyle from the population. Besides, in public utilities sphere (unlike manufacturing) energy has no real replacement. The lack of price elasticity of demand has its limits. It exists only when the share of expenses on electricity is no higher than $10 \%$ of income. For population of Khabarovsk Krai the share of expenses for the poorest group was $6.1 \%$, and $0.8 \%$ for the high-income populace. The price elasticity of demand coefficient for electricity is estimated at 0.3 for the Khabarovsk Krai population.

Important to note that the lack of price elasticity of demand can be objectively influenced by subsidized tariffs that are actually below the real costs. But then the question is, how heavy would be the burden on households if the tariffs grew?

\section{Estimating the consequences of tariffs growth for population: Khabarovsk Krai}

The structure of payment redistribution is as follows: the population is pay for the majority of costs carried by the producers $(65.2 \%$ for electricity and $49.1 \%$ for heat energy); the state compensates the loss of income experienced by the producers of energy due to welfare benefits and subsidies for socially vulnerable population: $25 \%$ for electricity and $43.6 \%$ for heat, which traditionally dominate among public utilities payments; the cross subsidies range between $7-10 \%$ [18, p. 22].

The However, the burden on households in Khabarovsk Krai is extremely unequal. When looking at the $20 \%$ groups of population depending on the volume of disposable income the first group with the lowest income spends $18.2 \%$ of that income on energy, the second group $-10.1 \%$, etc., the fifth group with the highest income - no more than $2.5 \%$ of the average disposable income per capita. This means it is very important to monitor financial consequences for households in case of increasing tariffs on electricity and heat supply.

Two future scenarios are possible: (1) tariff increment matches inflation at 4\% annually; (2) tariff increment is kept at the level of previous 5 years, $105.6 \%$ annually. For disposable income, the growth rates of the recent years for all five income groups were kept as is. Even if the quality of life changes for the better, in this case it is more important to establish a risk zone for solvency and potential need for state patronage over essential sphere for life and activity. The thresholds for this risk zone are the so-called "availability thresholds" established by Bashmakov I.A. [19] The "average availability threshold" denotes that the share of expenses on public utilities in population income is above $7-8 \%$, of energy service $-3-4 \%$, which leads to the loss of comfort and decreases payment discipline.
The second, "marginal availability threshold", means that the share is $15 \%$ for public utilities and $6-8 \%$ for energy services. When this threshold is crossed, "no harsh measures in attempting to collect payments or supporting population will improve payment discipline. This threshold is the key in creating social support programs" [20].

The calculations show that (Table 1):

- In scenarios (1) and (2) the burden on households in the lowest-income group will cross the $20 \%$ threshold by 2025 and will be unbearable, causing lack of payments and high debt.

- For groups II and III both scenarios show burden reaching above $8 \%$ - the aforementioned "marginal availability threshold", which is followed by the decreasing payment discipline and the negative consequences for energy suppliers;

- For the most fortunate groups IV and $\mathrm{V}$ the high growth of tariffs will not increase the share of energy payments above critical levels, but this does not mean that their payment discipline would not change.

Table 1. The share of electricity and heat expenses in disposable income of the Khabarovsk Krai population divided into $20 \%$ groups, $\%$

\begin{tabular}{|l|c|c|c|}
\hline \multirow{2}{*}{ Group } & \multirow{2}{*}{2017} & \multicolumn{2}{c|}{ Estimate 2025 } \\
\cline { 3 - 4 } & & $\begin{array}{c}\text { scenario } \\
(1)\end{array}$ & $\begin{array}{c}\text { scenario } \\
(2)\end{array}$ \\
\hline $\begin{array}{l}\text { Group I } \\
\text { (lowest income) }\end{array}$ & 18.2 & 22.1 & 25.4 \\
\hline Group II & 10.1 & 11.8 & 13.6 \\
\hline Group III & 7.0 & 8.0 & 9.2 \\
\hline Group IV & 4.8 & 5.4 & 6.2 \\
\hline $\begin{array}{l}\text { Group V } \\
\text { (highest income) }\end{array}$ & 2.4 & 2.6 & 3.0 \\
\hline
\end{tabular}

This means that if the tariffs on energy continue to advance rapidly, by 2025 the first three income groups in Khabarovsk Krai would cross the availability threshold, worsening their comfort level and becoming dependent, eventually transforming into insolvent.

Undoubtedly the state's involvement into this situation is necessary and is not just a goodwill act to support the poor, but the purposeful fulfillment of its social duties. In particular, supplying its citizens with social support (benefits) in paying for housing and public utilities.

The budget of Khabarovsk Krai in 2019 spent 3.2 billion rubles on compensating benefits, while subsidies for socially vulnerable population took only 770 thousand rubles. Where subsidizing correlates with the quality of life in the region, providing benefits depends on the goals and scale of the federal and regional social policy. This means that if the tariffs on energy grow 
(which occupy more than half of expenses on public utilities) and even if poverty decreases, the large share of state's financial burden would be devoted to fulfilling its social duties. The total expenses of Khabarovsk Krai budget on supporting its population by 2025 can reach:

a) in scenario 1 (tariffs match inflation) -5.6 billion rubles annually,

b) in scenario 2 (maintaining tariff growth) -6.3 billion rubles annually.

This presumes that the Far East maintains the existing patronage in setting tariffs below the level of real expenses. Cancelling it would decrease the quality of life, increase the level of non-payments, and increase the expenses of local budgets on compensating them.

\section{Conclusions}

This research has allowed to formulate the following conclusions. The estimations of price elasticity of demand on electricity in the conditions of surplus energy systems of the Far East confirm earlier assumptions of the lack of elasticity of demand on energy.

If the tariffs grow, the financial burden on household will significantly differ depending on the income levels of population of the Far East, especially Khabarovsk Krai, meaning: a) about two thirds of the population would experience a worsening quality of life; b) no less than $40 \%$ would become unable to pay; c) no less than $20 \%$ would cross the "marginal availability threshold", creating a category of stagnant poverty.

If energy costs were to increase, the subsidiary burden of territories of the Far East would increase 1.5 times, specifically in Khabarovsk Krai, which maintains a vast array of federal and regional benefits and a narrow window of work and increased income opportunities for the population, $20 \%$ of which require state support.

The correct choice of dominants of energy policy in the social sphere and public utilities sphere help foster favorable conditions in the society, because without a reliable electricity, heat and fuel supply not only do the economic, social, and political risks grow, but so do the costs of overcoming them.

\section{References}

1. I. A. Bashmakov, M.G. Dzedzichek, Assessment of Cost of Energy Supply in the Regions of Extreme North, Energy Conservation, 4 (2017).

2. A.S. Nekrasov, V.V. Semikashev, Energy costs in Russian households, HSE Economic Journal, 10, 3, 448-471 (2006) (In Russian).

3. S.N. Naiden, O.V. Dyomina, Solvent Demand in the Far East Electric and Thermal Energy Markets, Regionalistics, 6, 6, 64-76 (2019) DOI: 10.14530/reg.2019.6.64

4. O.V. Dyomina, The Specific Features of Development of the Regional Energy Systems and District Heating Systems. Regionalistics, 4, 5, 35-49 (2017) DOI: 10.14530/reg.2017.5
5. A.A. Beschinskiy, Yu.M. Kogan, Economic Problems of Electrification, Moscow (1983).

6. Coming in from the Cold. Improving District Heating Policy in Transition Economies, OECD, IEA (2006) URL: http://www.iea.org/publications/freepublications/pu blication/cold.pdf.

7. A.S. Nekrasov, S.A. Voronina, V.V. Semikashev, Problems of Residential Heat Supply in Russia, Studies on Russian Economic Development, 23, 2, 128-134 (2012).

8. S. Stoft, Power System Economics: Designing Markets for Electricity John Wiley \& Sons, New York (2002).

9. Ben W.F. Depoorter, Regulation of Natural Monopoly (1999) URL: https://reference.findlaw.com/lawandeconomics/540 0-regulation-of-natural-monopoly.pdf

10. A.S. Nekrasov, V.V. Semikashev, Energy Expenditures in Russian Households, Studies on Russian Economic Development, 16, 6, 592-597 (2005).

11. S.N. Naiden, O.V. Dyomina, Heat Supply Reform: Consequences for the Consumers in the Far East, ECO, 3, 21-36 (2019). DOI: 10.30680/ECO01317652-2019-3-21-36.

12. N.V. Antonov, L.I. Tatevosova, Dynamics of the energy intensity of the Russian economy in 20062007 and projections of the energy consumption. Problemy prognozirovaniya. [Forecasting Problems]. 3, 77-91 (2009).

13. I.A. Bashmakov, The Experience of the Parameter Estimates of the Price Elasticity of Energy Demand. Moscow: Center for Energy Efficiency. (2007) http://www.cenef.ru/file/Bpaper100.pdf

14. V.A. Volkonskij, A.I. Kuzovkin, Price and financial problems of the fuel and energy complex, Moscow, (2008).

15. I.V. Galperova, I.D. Kononov, O.V. Mazurova, Forecasting the demand for energy sources in balance with their prices, Region: ekonomika $i$ sotsiologiya. [Region: Economics and Sociology], 3, 207-219 (2008).

16. Yu.N. Kucherov, Yu.M. Kogan, N.L. Avdeeva, An example of the assessment of the relationship between the social and economic development of Russia and the need for electricity, Toplivnoenergeticheskiy kompleks. [Fuel and energy complex], 1-2, 132-138 (2005).

17. A.V. Mishura, Assessing energy demand elasticity of major industrial producers in Russia, Region: ekonomika i sotsiologiya. Region: [Economics and Sociology], 2, 110-124 (2009).

18. S.N. Naiden, O.V. Dyomina, Demand of the population for the power supply services in the southern zone of the Far East, Vlast' $i$ upravleniye na Vostoke Rossii. [Power and Administration in the East of Russia], 3 (84), 17-25 (2018). DOI 10.22394/1818-4049-2018-84-3-17-25.

19. I.A. Bashmakov, Housing and utilities reform: are we wrong to do what we are planning or wrong to 
do what we are doing? Energosberezheniye. [Energy Conservation ], 5, 18-25 (2004).

20. Energy use and energy efficiency in the Russian housing sector. How to make it low carbon? Ed. by I.A. Bashmakov. Moscow: Center for Energy Efficiency, (2014). 